\title{
Trees in the landscape: towards the promotion and development of traditional and farm forest management in tropical and subtropical regions
}

\author{
Paxie W. Chirwa $\cdot$ William Mala
}

Received: 14 July 2016/ Accepted: 16 July 2016/Published online: 21 July 2016

(C) Springer Science+Business Media Dordrecht 2016

\begin{abstract}
This introductory paper aims to synthesize the findings on on-farm trees research with the integration of traditional silvicultural knowledge on multipurpose trees for the design of small scale forestry practices in Africa and Asia. The science, socio-economics and governance aspects of traditional tree based management systems have been documented through the different papers. The findings provide a synopsis of on- farm tree management in Africa and Asia. The synthesis shows that there are still important knowledge gaps such as the ownership of land and trees, gender, the motivation to invest on farm trees, income and livelihood strategies and ecological issues of on farm trees in the context of climate change adaptation and sustainable development goals. There is a general consensus that successful implementation of community involvement in natural resource management in Africa and Asia will only be realized by implementing enabling policies on land tenure, devolution for full
\end{abstract}

P. W. Chirwa ( $\square)$

Department of Plant and Soil Sciences, University of Pretoria, RM5-15, Plant Sciences Complex, Hatfield, Pretoria 0028, South Africa

e-mail: paxie.chirwa@up.ac.za

W. Mala

Department of Plant Biology, University of Yaoundé I, PO Box 337, Yaoundé, Cameroon

e-mail: williammala@yahoo.fr empowerment visa viz planning, beneficiation and sharing of benefits.

Keywords Climate change $\cdot$ Communities $\cdot$ Natural resource management $\cdot$ Policies $\cdot$ Traditional agroforestry systems

\section{Introduction}

In the tropics, the agro-ecosystems are complex and diversified as they respond to human resource uses. These ecosystems include, by definition, people and their institutions, as well as the agricultural biodiversity and trees in the landscape that they use and influence through their diverse range for their livelihood and well-being. Trees in the landscape represent a key element in managing the relationship between forest and agriculture that result into agricultural biodiversity in traditional forest land use management (Mala 2009; Oteng-Yeboah et al. 2011). Agricultural biodiversity is the result of the interactions between the environment, genetic resources, and the management systems and practices used that have been combined, modified and managed by people for millennia, in complex and diverse agricultural systems (FAO 1999; Chirwa et al. 2008; Kalaba et al. 2010). While these human-nature processes for managing agricultural biodiversity have been documented in the tropics, the relationships between the management of 
trees and the dynamics of land use systems remain poorly investigated as well as their adaptability to the traditional forest management systems (FAO 1999; Mala 2009). In addition, advances made in developing sustainable forest agricultural landscape mosaics in the tropics have concentrated on the improvement of a limited number of agricultural crops and selected non timber forest products (Mala et al. 2008).

Furthermore, the thinking and processes on sustainable forest-agriculture have been dominated over the past years by approaches that have sought to separate forests and agriculture spatially, administratively and conceptually into two separate units for management and research (Diaw et al. 2009) Thus conventional silviculture practices for forest plantations concessions are erroneously applied to forest systems that traditionally are managed as community based natural resources systems (Hardcastle et al. 1998). On the other hand, the traditional management systems in the tropics are a continuum of forestryagriculture in different forms; and these systems have been managed for millennia using existing traditional institutional frameworks that also take cognisance of the attitudes and local knowledge of the communities (Nair 1989; Wiersum 1997; Acheampong 2003). In fact, that is why many governments in the tropics have adopted policies that promote community management of natural resources (Roe et al. 2009). Many countries in both Africa and Asia have promoted various forms of community forestry management with reports of success being limited by poor policies on tree and land tenure (Agarwal 2001) and unclear mechanisms for sharing benefits.

This paper aims to provide a synthesis of research conducted to document on-farm trees research and the related integration of traditional silviculture based on the knowledge of multipurpose trees for the design of small scale forestry practices in Africa and Asia. The papers fall under two main themes: (i) socio-ecological management of trees in traditional agroforestry systems and (ii) governance mechanisms and participatory forest management of forest resources.

\section{Socio-ecological management of trees in traditional agroforestry systems}

The dry land forests, woodlands and the savanna parklands are the most human dominated agroecosystems in Africa. While literature has in the past shown that traditional shifting cultivation system or slash \& burn agriculture have resulted in the degradation of the land cover, recent findings in the miombo woodland have shown that some abandoned woodlands recover once the disturbance ceases (Syampungani 2008, Syampungani et al. 2015). In fact, the findings in this issue indicate that disturbance if properly managed creates a conducive environment for the key miombo species which are light demanding and require maximum exposure to sunlight (Syampungani et al. 2015). Thus, systems that provide a livelihood like charcoal production and slash \& burn agriculture may be necessary disturbances that enhance the establishment and development of the regeneration pool of the miombo woodland systems (Syampungani et al. 2015).

In West Africa, traditional agroforestry systems have been modified to promote economic crops such as the cocoa and doum palm. A number of studies have been reported on the socioeconomic dynamics of these systems (Bhagwat et al. 2008; Anglaaere et al. 2011; Asare et al. 2014). In the cocoa agroforestry system (CAFS) highlighted in this issue, it has been shown that these systems can conserve up to $46 \%$ of forest species found in nearby forests (Mbolo et al. 2016). In this case, compared to monocropping, CAFS can act as reservoirs for the conservation of forest tree species. In a study that considered the stand structure and spatial patterns of an over harvested Hyphaene thebaica Mart. (doum palm) an agroforestry tree species in farmlands versus protected area of Biosphere Reserve of Pendjari (BRP) in Benin, it was shown that the species is still well preserved in both farmlands and BRP due to its longevity, low adult mortality rates and traditional management practices (Idohou et al. 2016). However, there are concerns for the rapid land-use intensifications that may lead to increasing pressure on the species populations in the future. This is typically similar to other important species in the African landscape such as Adansonia digitata that is subjected to clearing for agricultural expansion and exploitation for other non-timber forest use (Assogbadjo et al. 2008; Venter and Witkowski 2013).

As earlier discussed, agroforestry systems encompass a wide variety of practices, including crop-fallow rotations, complex agroforests, simple agroforests, silvopastoral systems, and urban agroforestry (Nair 1989). According to the IPCC, agroforestry systems 
can be superior to other land uses at the global, regional, watershed, and farm scales because they optimize trade-offs between increased food production, poverty alleviation, and environmental conservation. It is also recognized that agroforestry can be inefficient when the technology is inappropriate or the accompanying policies are not enabling. Mbow et al. (2014) further contend that combining adaptation with mitigation has been recognized as a necessity in developing countries, particularly in the agriculture, forestry and other land use (AFOLU) sector. Thus other than carbon sequestration, recognizing cobenefits from traditional agroforestry systems is crucial. In reality, there is no dissociation between crop production and other ecosystem services from land use (Mala et al. 2008). This has been well encapsulated in the analysis by Gokowski et al. (2001) in Cameroon where they analysed trade-offs between carbon sequestration and farmer profitability in a range of agroforestry practices. Most agroforestry systems fell in the medium carbon to low profit and/or high profits.

In this issue, the potential and the associated pros and cons of agroforestry in climate change mitigation are highlighted with a case study from the Indian subcontinent where previously economic domestication of Dyera polyphylla (Miq.) Steenis was practiced in peatlands agroforestry systems in Jambi Indonesia for latex production (Tata et al. 2015). An innovative approach has been to experiment the modification of this existing agroforestry system by mimicking a forest transition system where it has been shown that jelutong could be planted in various mixed systems of agroforestry, from rubber, coffee to oil palm. This is further demonstrated with a review of the carbon sequestration potential of agroforestry in the Indian sub-continent. It is argued that the green revolution and/or smart agriculture have been at the expense of natural resources and degradation of the environment. (Sharma et al. 2015). While the review seems to advocate the use of climate smart agriculture agroforestry, it is recognized that there is very limited adoption. It is suggested that potential climate smart agroforestry interventions must have both practical and biophysical potential for registration under clean development mechanism for additional income. An indeed like all other CDM projects, there is a need to address the technical, economic, legal and social issues and procedures and methodologies for carbon accounting, etc., which requires thorough review to develop appropriate models for payments of environmental benefits.

Finally, while traditional agroforestry systems have somehow withstood the test of time, the current socioeconomic dynamics, as earlier alluded to, have affected their continued adoption. For example, the increasing human population has meant other AFS cannot continue to be practiced in their original approach, such as slash and burn agriculture. In addition, the government policies in many countries have not been enabling enough to promote clear land and tree tenure. This is especially important it terms of tree tenure and gender where for example women have no land while some trees are said to belong to the state. Some studies have shown a marked improvement in tree planting with improved policies (Maisharou et al. 2015). In this issue, a study from Malawi examined farmers' beliefs, attitudes and behaviours in relation to planting trees on farms and cutting down trees from the forest. Meijer et al. (2015) showed that farmers recognise both the benefits of planting trees and negative effects of cutting down trees from the forest. The study highlights the importance of linking tree planting with the integrated land use approach of reconciling livelihood improvement and forest conservation in developing countries in order to have a win-win scenario. Hence understanding the trade-offs as highlighted earlier between forest conservation and livelihood benefits are important for the effective design and implementation of sustainable agricultural interventions.

\section{Governance mechanisms and participatory forest management of forest trees resources}

Many policy makers, planners and practitioners now agree that increased stakeholder participation in forest management has proved to be cost effective, socially just and environmentally sound (Castro and Nielsen 2001). This is based on the assumption that involvement of local communities can improve forest condition and utilization. Local responsiveness is increased if the institutional arrangements put in place facilitate good communication and learning among stakeholders (Wollenberg et al. 2004). However, there is a need to ensure that genuine power to make decisions regarding management and utilization of resources should be devolved to and within local communities 
supported by the policy environment (Castro and Nielsen 2001; Knox and Meinzen-Dick 2001; Shrestha and McManus 2006). Local empowerment, decentralization of decision making and increased involvement of local communities in forest management should ultimately result in changes in forest ownership and tenure (Phiri et al. 2012). Clarity and security of tenure are fundamental to participatory forest management (PFM) because communities cannot invest time and money in PFM activities if they are unsure of their access and usufruct rights to the resource.

'Participatory forestry' or 'participatory forest management (PFM)' is one of the approaches that are being used to deal with the challenges of conflicting claims and interests of stakeholders in forestry. PFM represents a new set of partnerships between the state (usually forest departments) and communities in and adjacent to forest areas (Schreckenberg and Luttrell 2009; Islam et al. 2015). It includes activities such as community forestry, co-management or joint forestry management and community based natural resource management (CBNRM). The difference between PFM activities comes in the institutional arrangement, which ranges from community owned and managed forest resources to partnership between state and local communities in state forests. Through partnerships, communities gain additional rights and powers, and share in the benefits; however, the state retains ownership of the resource and the right to approve and enforce the agreement (Arnold 2001; Schreckenberg and Luttrell 2009). Schreckernberg and Luttrell (2009) have defined participatory forestry as processes and mechanisms that enable those people who have a direct stake in forest resources to be part of decision-making in all aspects of forest management, from managing resources to formulating and implementing institutional frameworks. More specifically, community forestry refers to a component of participatory forestry that focuses on local communities as key stakeholders for sustainability.

PFM or community involvement in management of forest resources aims at addressing issues that include reducing the role of and cost to government in management of forests; achieving effective resource management through involvement of adjacent communities; protection of rural livelihoods through local control; developing locally responsive institutions that harness local skills, motivation and labour for efficient management of forests; and ensuring that local people's participation is based on principles of selfdetermination and democracy (Kajembe and Kessy 2000; Menzies, 2002; Edmunds and Wollenberg 2003). For PFM to work there has to be real power transfer.

For participatory forestry programmes, some studies reported that people had positive attitudes towards them and were more willing to participate in programme activities (Agea et al. 2009; Kobbail 2012; Matiku et al. 2012). These positive attitudes were attributed to increased understanding of PFM, the impact of the programme on livelihoods, and cordial relationships with forestry staff. In other instances, however, participation in these programmes was negatively associated with attitudes, and people were wary of taking over responsibilities of managing the resources (Macura et al. 2011; Obua et al. 1998). The differences in attitudes suggest that strategies to involve people in participatory programmes should recognize positive and negative attitudes to reflect that communities are not homogeneous.

In this issue, a variant of community participation is reported in the form of the Taungya system which was piloted to improve the livelihoods of the forest communities while restoring the forest to improve timber production in Ghana. As discussed above, the main challenges identified were the management system such as the lack of alternative livelihoods between tree planting and end of the rotation of the trees and clear benefit sharing mechanisms among the farmers and also between the state and the communities (Acheampong et al. 2016). Indeed the attitudes of the communities/farmers to the project were further compromised due to the choice of especially the agricultural crops allowed in the system. Furthermore, the findings indicate that the quality of partnership matters in the performance of the scheme: a comanagement arrangement exclusively between the state (Forestry Commission) and the farmer groups generates poorer results in terms of the quality of the timber stands, income-generating potential and motivation of the actors involved. This is in contrast to the study from South Africa where the state is in the process of empowering communities to be involved in forest plantations due to the recent land dynamics where most of state plantations have been scheduled for transfer to community-based entities (Munyanduki et al. 2015). In this regard, determination of the 
potential alternative management types is vital. In this case, the communities perceived that the involvement of the state in the form of joint forest management (JFM) was the optimal plantation management regime across all indicators while expressing total lack of confidence in managing the plantations communally. This is certainly a new direction in the South African contest with many models of engagement between the states; public-private partnerships being tested for the future development of the forestry industry in the country (Chirwa et al. 2015).

Finally, this issue interrogates the notion that participatory forest management can lead to efficient forest resource use and improvement of the rural livelihoods with a study from Malawi. The study evaluated the program that was specifically aimed at alleviating poverty and enhancing rural livelihoods through promoting greater community involvement in forest management while providing access and associated benefits (Senganimalunje et al. 2015). The findings suggest that communities are still restricted to subsistence use and not forest enterprising to move out of poverty. The main conclusion mirrors the findings from Ghana (Acheampong et al. 2016) that the introduction of the co-management program did not bring out the expected outcomes in areas of community organization, forest access, forest product availability and commercialisation of forest products. Both studies also seem to suggest that a multi-institutional approach important to draw upon diverse talents and experiences from individual institutions both government and non-governmental in order to achieve meaningful social change.

\section{Conclusions}

The findings provide a synopsis of on farm trees management in Africa and Asia. However, there are still important knowledge gaps highlighted such as ownership of land and trees, gender, the motivation to invest on farm tree, income and livelihood strategies and ecological issues of on farm trees in the context of climate change adaptation and sustainable development goals. Lastly, the studies presented in this issue still cast doubt on successful implementation of community involvement in natural resource management with policies on land tenure, devolution for full empowerment visa viz planning, beneficiation and sharing of benefits as still outstanding in many parts of Asia and Africa.

\section{References}

Acheampong E (2003) Sustainable livelihoods of forest fringe communities: forests, trees and household livelihood strategies in southern Ghana. PhD Thesis, University of Hull, UK

Acheampong E, Insaidoo TFG, Ros-Tonen MAF (2016) Management of Ghana's modified taungya system: challenges and strategies for improvement. Agrofor Syst. doi:10.1007/ s10457-016-9946-7

Agarwal B (2001) Participatory Exclusions, Community Forestry, and Gender: An Analysis for South Asia and a Conceptual Framework. World Dev 29(10):1623-1648

Agea JG, Nansereko S, Obua J, Waiswa D, Buyinza M, Yikii F (2009) Attitudes of out-of-school youths towards tree planting activities in central Uganda: a case study of Masaka District. Discov Innov 21:111-118

Anglaaere LCN, Cobbina J, Sinclair FL, McDonald MA (2011) The effect of land use systems on tree diversity: farmer preference and species composition of cocoa-based agroecosystems in Ghana. Agrofor Syst 81:249-265

Arnold JEM (2001) Forests and people: 25 years of community forestry. FAO, Rome

Asare R, Afari-Sefa V, Osei-Owusu Y, Pabi O (2014) Cocoa agroforestry for increasing forest connectivity in a fragmented landscape in Ghana. Agrofor Syst 88:1143-1156

Assogbadjo AE, Glelekakai R, Kyndt T, Sinsin B (2008) Folk classification, perception, and preferences of baobab products in West Africa, consequences for species conservation and improvement. Econ Bot 62:74-84

Bhagwat SA, Willis KJ, Birks HJB, Whittaker RJ (2008) Agroforestry: a refuge for tropical biodiversity? Trends Ecol Evol 23:261-267

Castro AP, Nielsen E (2001) Indigenous and co-management: implications for conflict management. Environ Sci Policy 4:229-239

Chirwa PW, Akinnifesi FK, Sileshi G, Syampungani S, Kalaba FK, Ajayi OC (2008) Opportunity for enhancing agrobiodiversity through agroforestry in Southern Africa. Biodiversity 9:45-48

Chirwa PW, Mamba S, Manda SM, Babalola FD (2015) Assessment of settlement models for engagement of communities in forest land under claim in Jessievale and Roburna communities in Mpumalanga, South Africa. Land Use Policy J 46:65-74

Diaw MC, Aseh T, Prabhu R (2009) In Search of Common Ground: Adaptive Collaborative Management in Cameroon. Center for International Forestry Research (CIFOR), Bogor

Edmunds D, Wollenberg E (2003) Whose devolution is it anyway? Divergent constructs, interest and capacities between the poorest users and states. In: Edmunds D, Wollenberg E (eds) Local forest management: The impacts of devolution policies. Earthscan, London, pp 150-165

FAO (1999) Sustaining agricultural biodiversity and agroecosystem functions : Farming Systems Approaches for the 
Sustainable Use and Conservation of Agricultural Biodiversity and Agro-Ecosystems. Report of International Technical Workshop organized jointly by the Food and Agriculture Organization of the United Nations and the Secretariat of the Convention on Biological Diversity, with the support of the Government of the Netherlands, 2-4 December 1998. Rome: Food and Agricultural Organization

Gockowski J, Nkamleu GB, Wendt J (2001) Implications for resource use intensification for the environment and sustainable technology systems in the central African rainforest. In: Lee D, Barrett C (eds) Tradeoffs and synergies: Agricultural intensification, economic development and the environment. CABI, London, pp 197-219

Hardcastle PD et al (1998) Silvicultural options for the rainforest zone of Cameroon. Report prepared for the Government of Cameroon under assignment from the British Department for International Development, June, 1998

Idohou R, Assogbadjo EA, Azihou F, Kaka1 RG, Adomou A (2016) Influence of the landscape context on stand structure and spatial patterns of the doum palm (Hyphaene thebaicaMart.) in the Republic of Benin (West Africa). Agroforest Systems DOI 10.1007/s10457-016-9920-4

Islam KK, Jose S, Masakazu T, Kimihiko H, Krott M, Sato N (2015) Does actor power impede outcomes in participatory agroforestry approach? Evidence from Sal forests area, Bangladesh. Agrofor Syst 89:885-899

Kajembe GC, Kessy JF (2000) Joint forest management in Urumwa Forest Reserve, Tabora, Tanzania: A process in the making. In: Virtanen P, Nummelin M (eds) Forests, chiefs and peasant in Africa: Local management of natural resources in Tanzania, Zimbabwe and Mozambique. Silva Carelica 34. University of Joensuu, Finland, pp 141-158

Kalaba FK, Chirwa PW, Syampungani S, Ajayi OC (2010) Contribution of agroforestry to biodiversity and livelihoods improvement in rural communities of Southern African regions. In: Tscharntke Teja, Leuschner Christoph, Veldkamp Edzo, Faust Heiko, Guhardja Edi, Bidin Arifuddin (eds) Tropical rainforests and agroforests under global change. Springer, Berlin, pp 461-476

Knox A, Meinzen-Dick R (2001) Collective action and property rights and devolution of natural resource management: Exchange of knowledge and implications for policy. CAPRi Working Paper No. 11

Kobbail AAR (2012) Local people attitudes towards community forestry practices: a case study of Kosti Province - central Sudan. Int J For Res 2012:1-7

Macura B, Zorondo-Rodríguez F, Grau-Satorras M, Demps K, Laval M, Garcia CA, Reyes- García V (2011) Local community attitudes toward forests outside protected areas in India. Impact of legal awareness, trust, and participation. Ecol Soc 16(3):10

Maisharou A, Chirwa PW, Larwanou M, Babalola FD, Ofoegbu C (2015) Sustainable Land Management Practices in the Sahel: review of Practises, Techniques and Technologies for Land Restoration and Strategy for Up-Scaling. Int For Rev 17(S3):1-19

Mala, A.W. 2009. Knowledge Systems and Adaptive Collaborative Management of Natural Resources in southern Cameroon: Decision Analysis of Agrobiodiversity for
Forest-Agriculture Innovations. PhD Dissertation. Stellenbosch: Stellenbosch University

Mala AW, Geldenhuys J Coert, Prabhu R (2008) A predictive model of local agricultural biodiversity knowledge management in Southern Cameroon. Biodiversity $9(1$ \& 2):96-101

Matiku P, Mireri C, Ogol C (2012) Does participatory forest management change household attitudes towards forest conservation and management? Afr J Environ Sci Technol 6(5):237-346

Mbolo AMM, Zekeng JC, Mala AW, Fobane Chimi DC, Ngavounsia T, Nyako CM, Etoundi MFL, Tamanjong YV (2016) The role of cocoa agroforestry systems in conserving forest tree diversity in the Central region of Cameroon. Agrofor Syst. doi:10.1007/s10457-016-9945-8

Mbow C, Smith P, Skole D, Duguma L, Bustamante M (2014) Achieving mitigation and adaptation to climate change through sustainable agroforestry practices in Africa. Curr Opin Environ Sustain 6:8-14

Meijer SS, Sileshi GW, Catacutan D, Nieuwenhuis M (2015) Agroforestry and deforestation in Malawi: inter-linkages between attitudes, beliefs and behaviours. Agrofor Syst. doi:10.1007/s10457-015-9844-4

Menzies NK (2002) Global gleanings. Lessons from six studies of community based forest management around the world. A report prepared for the Ford Foundation's Environment and Development Affinity Group (EDAG)

Munyanduki P, Chirwa WP, Babalola DF (2015) A case study assessment of socio-economic sustainability and alternative management regimes for state forest plantations in Limpopo Province. Agrofor Syst, South Africa. doi:10. 1007/s10457-015-9842-6

Nair PKR (1989) Agroforestry Systems in the tropics. Springer, Netherlands

Obua J, Banana AY, Turyahabwe N (1998) Attitudes of local communities towards forest management practices in Uganda: the case of Budongo Forest Reserve. Commonw For Rev 77(2):113-118

Oteng-Yeboah A, Mutta D, Byarugaba D, Mala AW (2011) The African view of TK and SFM in Traditional Forest Related Knowledge and Forest Science Interface. In: John A Parrotta, Ronald Trosper (Eds), Traditional Forest Knowledge: Sustaining Communities, Ecosystems and Biocultural Diversity. Springer, Dordrecht, p 37-78

Phiri M, Chirwa PW, Watts S, Syampungani S (2012) Local community perception of joint forest management and its implications for forest condition: the case of Dambwa Forest Reserve in southern Zambia. South For: J For Sci 74:51-59

Roe D, Nelson F, Sandbrook C (eds.) (2009) Community management of natural resources in Africa: Impacts, experiences and future directions, Natural Resource Issues No. 18, International Institute for Environment and Development, London, UK

Schreckenberg K, Luttrell C (2009) Participatory forest management: a route to poverty reduction? Int For Rev 11(2):221-238

Senganimalunje TC, Chirwa WP, Babalola FD, Graham MA (2015) Does participatory forest management program lead to efficient forest resource use and improved rural livelihoods? Experiences from Mua-Livulezi Forest Reserve, Malawi. Agrofor Syst. doi:10.1007/s10457-015-9826-6 
Sharma R, Chauhan SK, Tripathi AM (2015) Carbon sequestration potential in agroforestry system in India: an analysis for carbon project. Agrofor Syst. doi:10.1007/s10457-0159840-8

Shrestha KK \& McManus P (2006) Collective action of local communities in forest conservation and utilisation: Critical reflections from Nepalese community forestry. IUFRO 3.08 Small Scale Forestry Conference, Dublin: Coford

Syampungani S (2008) Vegetation change analysis and ecological recovery of the Copperbelt miombo woodlands of Zambia. $\mathrm{PhD}$ Thesis, University of Stellenbosch, Stellenbosch

Syampungani S, Geldenhuys CJ, Chirwa WP (2015) Regeneration dynamics of miombo woodland in response to different anthropogenic disturbances: forest characterisation for sustainable management. Agrofor Syst. doi:10.1007/ s10457-015-9841-7
Tata HL, Van Noordwijk M, Widayati JA (2015) Domestication of Dyera polyphylla (Miq.) Steenis in peatlandagroforestry systems in Jambi, Indonesia. Agrofor Syst. DOI 10.1007/ s10457-015-9837-3

Venter SM, Witkowski TF (2013) Where are the young baobabs? Factors affecting regeneration of Adansonia digitata $\mathrm{L}$, in a communally managed region of southern African. J Arid Environ 92:1-13

Wiersum KF (1997) Indigenous exploitation and management of tropical forest resources: an evolutionary continuum in forest-people interactions. Agri Ecosyst Environ 63:1-16

Wollenberg E, Campbell B, Shackleton S, Edmunds D, Shanley P (2004) Collective action and property rights for sustainable development: Collaborative management of forests. IFPRI/CAPRi 